\title{
PENYULUHAN DAN PELATIHAN PEMBUATAN SABUN ABU GOSOK DARI LIMBAH MINYAK JELANTAH SEBAGAI MEDIA PENGHILANG MALAM BATIK PADA TANGAN PEMBATIK DI DESA BUGANGAN
}

\author{
Futya Millatina $^{1}$, Ika Yuliawati ${ }^{1}$, Ratna Sukmawati ${ }^{1}$ \\ ${ }^{1}$ Jurusan Teknik Kimia, PDD Politeknik Negeri Bandung \\ Email: futya.milatina.pdd@polban.ac.id
}

\begin{abstract}
Abstrak
Para pembatik di Desa Bugangan menggunakan solar atau premium untuk menghilangkan lilin/malam yang menempel pada tangan. Solar atau premium mempunyai dampak negatif terhadap kesehatan apabila digunakan sebagai media cuci tangan. Kegiatan pengabdian kepada masyarakat ini bertujuan sebagai pemberdayaan masyarakat dalam bentuk memberikan penyuluhan dan pelatihan bagi pengrajin batik tulis di Desa Bugangan tentang pembuatan sabun abu gosok dari limbah minyak jelantah sehingga diharapkan dalam kegiatan ini masyarakat mengetahui dampak negatif dari pembuangan minyak jelantah ke lingkungan dan penggunaan solar atau premium sebagai media penghilang malam serta dapat meningkatkan keahlian masyarakat dalam pembuatan sabun abu gosok berbahan dasar limbah minyak jelantah. Metode kegiatan menggunakan metode penyuluhan, pelatihan serta monitoring dan evaluasi. Metode penyuluhan digunakan pada kegiatan pemaparan materi mengenai dampak negatif penggunaan solar atau premium yang biasa digunakan oleh para pembatik dan pemanfaatan minyak jelantah yang dapat digunakan untuk bahan dasar pembuatan sabun abu gosok. Metode pelatihan dan pendampingan digunakan pada kegiatan pembuatan sabun abu gosok dari minyak jelantah. Monitoring dan evaluasi dilakukan untuk memonitoring dan mengevaluasi produk sabun abu gosok yang telah dibuat oleh peserta. Kegiatan pengabdian masyarakat dinyatakan berhasil. Hal ini dapat dilihat dari $85 \%$ dari total peserta dapat menjawab post test dengan benar dan $82,5 \%$ dari total peserta dapat melakukan dan mengikuti cara kerja sesuai pada modul pelatihan.
\end{abstract}

Kata kunci: penyuluhan, pelatihan, sabun, penghilang malam

\section{PENDAHULUAN}

Desa Bugangan merupakan Desa yang terletak di Kecamatan Kedungwuni Kabupaten Pekalongan Propinsi Jawa Tengah. Masyarakat Desa Bugangan memiliki mata pencaharian yang beraneka ragam. Salah satu mata pencaharian masyarakat Desa Bugangan adalah sebagai pengrajin batik/pembatik. Batik yang dihasilkan merupakan batik tulis. Pengerjaan batik tulis menggunakan 
DIFUSI

Volume 3, No.1 Januari 2020

malam seringkali menempel pada tangan pembatik. Para pembatik di Desa Bugangan menggunakan solar atau premium untuk menghilangkan lilin/malam yang menempel. Solar atau premium mempunyai dampak negatif terhadap kesehatan apabila digunakan sebagai media cuci tangan secara kontinyu yaitu menimbulkan penyakit dermatitis [1]. Menurut Wardanang dkk (2014), abu gosok dari hasil pembakaran sekam padi merupakan media alternatif yang aman dan efektif sebagai pengganti solar dan premium dalam menghilangkan lilin/ malam pada tangan pembatik. Abu gosok sekam padi ditambahkan dengan sabun cair dapat menghilangkan lilin/malam lebih cepat dibandingkan tanah liat dan pasir dikarenakan teksturnya seperti scrub.

Penelitian yang telah dilakukan oleh Yuliawati, dkk [2] bahwa sabun abu gosok (sabun padat) mampu menghilangkan lilin/malam lebih cepat dan lebih bersih dibandingkan sabun padat tanpa kandungan abu gosok. Sabun abu gosok dibuat dalam bentuk padat dengan tujuan agar lebih efektif dan praktis dalam menghilangkan malam. Sabun padat juga lebih ekonomis dan mempunyai kestabilan fisik yang lebih baik dibandingkan sabun cair [1].

Pembuatan sabun padat dapat memanfaatkan limbah minyak jelantah. Minyak jelantah berpotensi sebagai bahan baku pembuatan sabun dengan dilakukan pengolahan atau pemurnian terlebih dahulu. Pengolahan atau pemurnian minyak jelantah dapat dilakukan melalui filtrasi (penyaringan) dan adsropsi menggunakan karbon aktif [3]. Minyak goreng bekas oleh masyarakat Desa Bugangan biasanya langsung dibuang ke lingkungan sehingga dapat menyebabkan pencemaran air maupun tanah. Pemanfaatan limbah minyak jelantah sebagai bahan baku pembuatan sabun akan meningkatkan nilai ekonomis dari minyak jelantah tersebut.

Kurangnya atau keterbatasannya pengetahuan masyarakat Desa Bugangan mengenai dampak negatif pembuangan minyak jelantah ke lingkungan dan penggunaan solar atau premium sebagai media penghilang malam khususnya bagi para pembatik dapat menimbulkan efek merugikan bagi lingkungan sekitar serta kesehatan dan apabila dilakukan secara terus menerus akan menjadi suatu kebiasaan yang tidak baik. Oleh karena itu, masyarakat Desa Bugangan membutuhkan penyuluhan mengenai dampak negatif yang ditimbulkan dari pembuangan minyak jelantah ke lingkungan dan penggunaan solar atau premium sebagai media penghilang malam serta pelatihan mengenai pemanfaatan limbah minyak jelantah sebagai bahan dasar pembuatan sabun abu gosok. Pelatihan tersebut juga diharapkan dapat memberikan keterampilan/keahlian masyarakat Desa Bugangan dalam membuat sabun abu gosok sendiri dari limbah minyak jelantah.

Berdasarkan analisis situasi tersebut, maka diadakan penyuluhan dan pelatihan pembuatan sabun abu gosok dari limbah minyak jelantah sebagai media penghilang malam batik pada tangan pembatik di Desa Bugangan 
DIFUSI

Volume 3, No.1 Januari 2020

\section{METODE}

Kegiatan Pengabdian kepada Masyarakat ini dilakukan dengan menggunakan beberapa metode yaitu :

\section{Penyuluhan Umum}

Penyuluhan umum dilakukan melalui pemaparan materi terkait dampak negatif penggunaan premium dan solar yang biasa digunakan oleh pembatik di Desa Bugangan untuk menghilangkan lilin/ malam yang menempel pada tangan, materi mengenai limbah minyak jelantah dan materi tentang manfaat limbah abu sekam padi. Kegiatan dilanjutkan dengan sesi tanya jawab sampai seluruh peserta kegiatan dapat memahami materi yang disampaikan oleh dosen/pemateri.

\section{Penyuluhan khusus}

Penyuluhan khusus dilakukan dengan membagi peserta menjadi 3 kelompok dengan cara tanya jawab dan diskusi kelompok.

\section{Pelatihan}

Metode ini berupa pelatihan dan pendampingan cara mengolah minyak jelantah untuk pembuatan sabun dan cara pembuatan sabun abu gosok dari minyak jelantah yang sudah diolah.

\section{Monitoring dan Evaluasi}

Metode yang dilakukan dalam tahap monitoring dan evaluasi adalah dengan melakukan evaluasi dari produk sabun yang dihasilkan melalui uji organoleptik dan mendatangi rumah para peserta kegiatan untuk memastikan para peserta telah beralih menggunakan sabun abu gosok untuk mencuci tangan setelah proses membatik.

\section{HASIL DAN PEMBAHASAN}

Kegiatan pengabdian masyarakat dilakukan di Desa Bugangan dengan melibatkan perangkat Desa, mahasiswa prodi D-II Teknik Kimia PDD polban dan para pembatik di Desa bugangan. Kegiatan dilakukan dalam tiga tahap yaitu penyuluhan, pelatihan serta monitoring dan evaluasi.

Tahap pertama pada kegiatan pengabdian masyarakat adalah dengan melakukan penyuluhan yang dilaksanakan di rumah salah satu pembatik Desa bugangan dengan peserta sejumlah 22 orang pembatik. Kegiatan pelatihan dibantu oleh 3 orang mahasiswa dari prodi D-II Teknik Kimia. Tahap awal pada kegiatan ini adalah melakukan pre test kepada para pembatik.

Penyuluhan dibagi menjadi dua sesi yaitu sesi penyuluhan secara umum melalui pemaparan materi oleh ketua tim pengabdian masyarakat dan penyuluhan khusus dengan membagi peserta kedalam tiga kelompok. Penyuluhan khusus dilakukan oleh seluruh tim pengabdian masyarakat melalui penjelasan dan diskusi pada masing-masing kelompok.

Kegiatan penyuluhan dilakukan dengan memberikan penjelasan kepada para pembatik akan dampak negatif dari solar/premium yang digunakan untuk mencuci tangan setelah membatik dan penjelasan mengenai limbah minyak jelantah dan abu gosok dari pembakaran sekam padi. Penjelasan dampak negatif 
penggunaan solar/premium bagi manusia diterangkan dari sisi kesehatan dan lingkungan. Dampak negatif dari penggunaan solar/premium dari sisi kesehatan adalah dapat menyebabkan iritasi pernafasan, pusing, mual dan pingsan. Paparan penggunaan solar/premium secara berulang dapat menyebabkan iritasi kulit atau gangguan kulit yang lebih serius [4]. Dampak negatif solar dari sisi lingkungan adalah dapat mencemari perairan, tanah dan udara.

Penjelasan mengenai limbah minyak jelantah diterangkan dari sisi negatif dan positif. Sisi negatif dari minyak jelantah dari segi kesehatan adalah apabila minyak jelantah dipakai kembali untuk proses memasak dapat menyebabkan kanker, memicu penyakit jantung koroner, struk dan hipertensi. Efek lain yang ditimbukan dari minyak jelantah yaitu dari segi lingkungan dapat mencemari lingkungan perairan dan mengurangi kesuburan tanah. Sisi positif dari minyak jelantah diterangkan bahwa minyak jelantah dapat digunakan untuk pembuatan sabun cuci tangan dengan melalui proses pemurnian minyak jelantah menggunakan arang batok kelapa yang mudah didapatkan di Desa Bugangan.

Penjelasan mengenai abu gosok dari pembakaran sekam padi diterangkan dari sisi positif bahwa abu sekam padi tersebut dapat dimanfaatkan untuk campuran pembuat sabun cuci tangan yang dapat dijadikan alternatif pencuci tangan pembatik yang ramah lingkungan dan aman dari segi kesehatan. Abu sekam padi bersifat abrasive (mampu menggosok). Sifat abrasive pada abu sekam padi dapat dimanfaatkan untuk bahan tambahan pembuatan sabun padat sebagai abrasive scrub yang berfungsi untuk membersihkan badan [5].

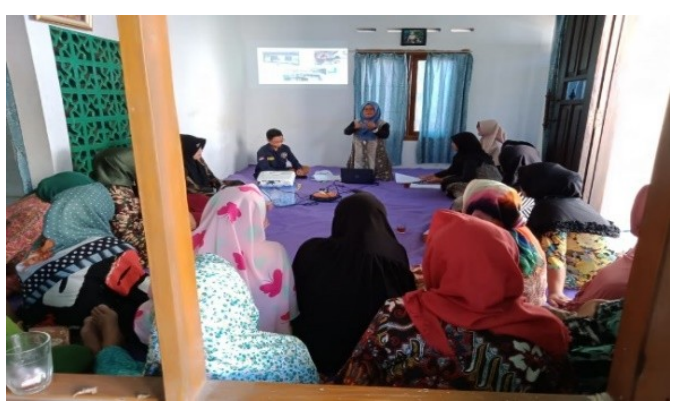

Gambar 1. Penyuluhan

Tahap kedua adalah pelatihan pembuatan sabun abu gosok yang dilaksanakan selama 2 hari. Kegiatan pelatihan dilakukan dalam tiga sesi yaitu pemaparan materi, praktek pemurnian minyak jelantah dan praktek pembuatan sabun abu gosok. Jumlah peserta yang hadir dalam kegiatan pelatihan berjumlah $30 \mathrm{o}-$ rang pembatik yang berarti bahwa 100\% target peserta mengikuti kegiatan pelatihan. Sejumlah 8 Peserta yang tidak mengikuti kegiatan penyuluhan diberikan sesi penyuluhan saat kegiatan pelatihan. Para peserta dibagi menjadi 6 kelompok dengan jumlah masing-masing 5 orang peserta tiap kelompok. Masingmasing kelompok dilatih oleh 2 orang pelatih yang terdiri dari dosen dan para mahasiswa. Kegiatan pelatihan dibantu oleh 12 orang mahasiswa D-II prodi teknik kimia.

Sesi pertama dari pelatihan yaitu pemaparan materi tentang bahan, alat serta metode yang digunakan untuk pembuatan sabun abu gosok dari minyak jelantah oleh ketua tim pengabdian masyarakat. Bahan yang digunakan untuk pembuatan sabun dijelaskan secara detail dari segi harga, kandungan, manfaat dan 
cara penggunaan bahan. Para peserta juga dijelaskan mengenai alat pelindung diri (APD) yang digunakan saat pembuatan sabun karena salah satu bahan pokok pembuatan sabun merupakan bahan yang bersifat alkali yaitu natrium hidroksida.

Sesi kedua dari pelatihan yaitu peserta PM melakukan praktek pemurnian minyak jelantah dengan didampingi oleh pelatih dari masing-masing kelompok. Minyak jelantah harus dilakukan proses pemurnian terlebih dahulu agar produk sabun aman digunakan untuk kulit. Bahan yang digunakan untuk memurnikan minyak jelantah adalah arang batok kelapa yang diaktifkan (arang aktif). Arang aktif dapat digunakan sebagai adsorben yang dapat menyerap polutan dan impuritis [6]. Arang aktif batok kelapa dimasukkan kedalam minyak jelantah dan didiamkan selama 24 jam. Arang aktif batok kelapa dipilih karena arang aktif batok kelapa merupakan salah satu jenis bahan yang dapat digunakan untuk pemurnian minyak jelantah yang mudah didapatkan di Desa bugangan.

Sesi ketiga adalah praktek pembuatan sabun abu gosok. Kegiatan pada sesi ini diawali dengan menyaring minyak jelantah yang sudah dimurnikan. Minyak yang telah disaring kemudian langsung diproses untuk pembuatan sabun abu gosok. Sabun yang dibuat oleh seluruh peserta PM 100\% berhasil mengalami proses saponifikasi dan menghasilkan produk sabun. Produk sabun yang telah dibuat oleh peserta menunjukkan bahwa peserta mampu mengikuti dan memahami proses pembuatan sabun abu gosok dari minyak jelantah dengan lancar. Hasil persentasi kemampuan peserta me- ngikuti cara kerja disajikan pada

Gambar 2.

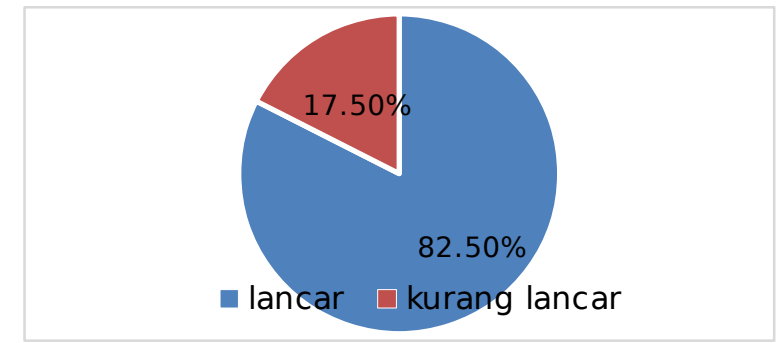

\section{Grafik 2. Persentasi Kelancaran Peserta Mengikuti Cara Kerja}

Gambar 2 menunjukkan bahwa 82,5\% peserta mampu melakukan dan mengikuti cara kerja sesuai modul dengan lancar dan benar. Hal ini sesuai dengan target luaran bahwa peserta mampu melakukan dan mengikuti cara kerja minimal $70 \%$ benar . Kegiatan pelatihan bisa dilihat pada Gambar 3. Kegiatan selanjutnya pada sesi praktek pembuatan sabun adalah diskusi dan pemberian post test.

Gambar 4 merupakan grafik hasil dari kemampuan peserta dalam menjawab pertanyaan post test. Berdasarkan Gambar 4 bahwa $85 \%$ peserta dapat menjawab pertanyaan dengan benar. Hal ini sesuai dengan target luaran kegiatan bahwa peserta mampu menjawab pertanyaan $70 \%$ minimal benar.

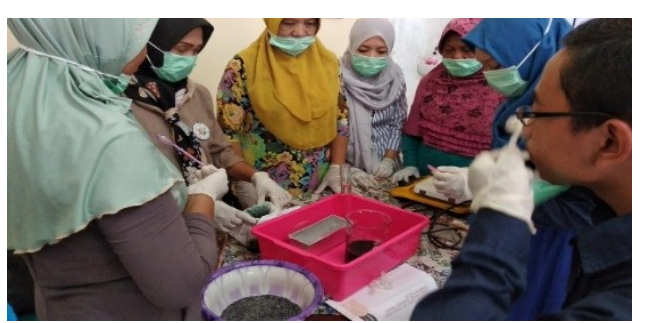

Gambar 3. Pelatihan 
DIFUSI

Volume 3, No.1 Januari 2020

Gambar 4. Kemampuan Peserta dalam Menjawab Post Test

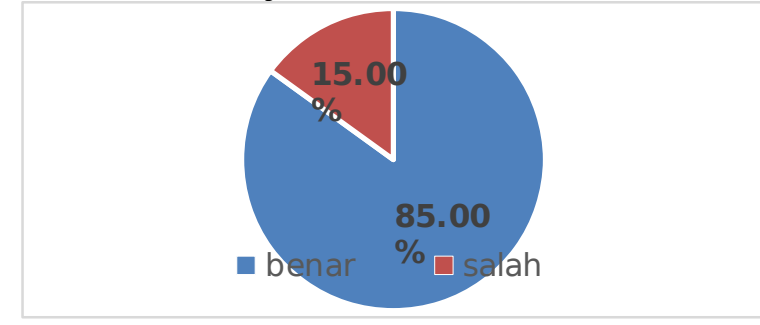

Kegiatan monitoring dan evaluasi (Gambar 5) dilakukan setelah produk sabun yang dibuat oleh peserta PM melewati proses curing yaitu 14 hari setelah proses pembuatan sabun. Monev dilakukan dalam dua tahap. Pada tahap pertama Tim PM melakukan evaluasi dari produk sabun yang dihasilkan melalui uji organoleptik. Sabun yang dihasilkan oleh masing-masing kelompok dinilai bagus dan dapat dikemas. Sabun yang telah dikemas dibagikan ke seluruh peserta PM.

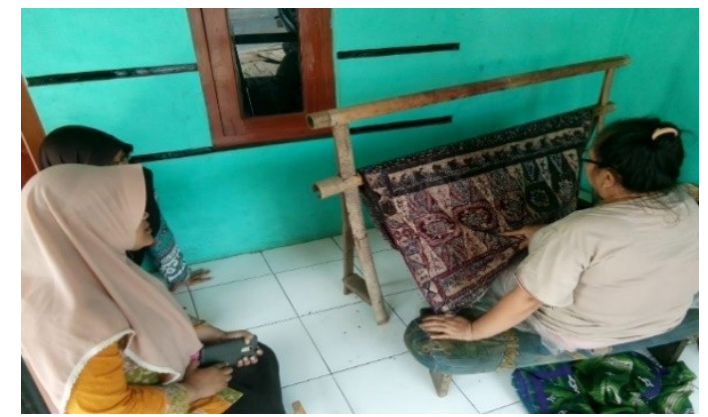

Gambar 5. Monitoring dan Evaluasi

Pada tahap 2 dilakukan dengan mengunjungi rumah para pembatik. Hasil dari kegiatan ini adalah para pembatik telah beralih menggunakan sabun abu gosok sebagai penghilang malam pada tangan pembatik karena sabun abu gosok dapat menghilangkan warna dengan lebih praktis dan aman bagi kulit. Para pembatik akan melakukan produksi sabun abu gosok bersama agar dapat diguna- kan sebagai persediaan untuk cuci tangan setelah membatik dengan lebih sehat.

\section{KESIMPULAN}

Program pengabdian masyarakat yang dilakukan oleh program studi D-II Teknik Kimia PDD POLBAN dan mitra pembatik di Desa Bugangan berhasil dilaksanakan dengan luaran yaitu:

1. Sejumlah $85 \%$ dari total peserta dapat menjawab post test dengan benar.

2. Sejumlah $82,5 \%$ dari total peserta dapat melakukan dan mengikuti cara kerja sesuai pada modul pelatihan.

\section{REFERENSI}

[1] C. Wardanang, P. S. Amalia, N. A. Erliana, R. Inayati, N. D. Nita, W. Tri, W. Vitri, W. Rita, Penggunaan Abu Gosok dan Sabun sebagai Media Alternatif Pengganti Solar dan Premium untuk Cuci Tangan Penghilang Lilin Malam Batik Prosiding Seminar Nasional Hasil, Purwokerto,. (2014).

[2] I. Yuliawati, M. Futya, S. Ratna,. Formulasi dan Analisis Sabun Abu Gosok sebagai Media Alternatif Penghilang Malam Batik pada Tangan Pembatik, Laporan Penelitian Pemula (Tidak dipublikasikan). Jurusan Teknik Kimia, Prodi D-II Teknik Kimia, PDD Politeknik Negeri Bandung. 2018.

[3] A. Prihanto, I. Bambang, Pemanfaatan Minyak Goreng Bekas menjadi Sabun Mandi Metana, Vol. 14 (2), pp. 55-59, 2018. 
DIFUSI

Volume 3, No.1 Januari 2020

[4] MSDS, Lembar Data Keselamatan Bahan (MSDS) Diesel Fuel (Solar). Waskita Karya, 2017

[5] I. M. Alam, Cosmetic Dermatology for skin of Color. The McGraw-Hill Companies, inc. United States, 2009.
[6] R. Paputungan, S. Nikmatin, A. Maddu, G. Pari, G. Mikrostruktur Arang Aktif Batok Kelapa untuk Pemurnian Minyak Goreng Habis Pakai. Jurnal Keteknikan Pertanian. Vol. 6, No. 1, 2018. 